\title{
Heroin in the hospice: opioids and end-of-life discussions in the 1980s
}

\author{
Cite as: CMAJ 2017 October 2;189:E1231-2. doi: 10.1503/cmaj.170720
}

n 1979, a Toronto-based celebrity doctor and syndicated columnist, Kenneth Walker, who wrote under the pseudonym W. Gifford-Jones, launched a campaign to legalize heroin (diacetylmorphine). Having lost close friends to cancer, Walker concluded that medical heroin was one answer to the problem of treating end-oflife pain associated with terminal cancer. His column, called "The Doctor Game," printed in about 40 newspapers across Canada, was his main platform. He also established the W. Gifford-Jones Foundation to solicit donations to "continue the fight." Much suffering, he felt, was a by-product of inadequate administration of existing analgesics, as well as unfair restrictions on heroin. Canadians were being denied access to this painkiller because of "political, not medical, decisions." Little did Walker realize that he would open "Pandora's box."1,2

His story embodies how the politics of pain, opioid addiction and proper end-of-life therapies present enduring challenges in a modern democratic society, which remains important in 2017. Medico-political calculations blend consumer protection, patient safety, crime prevention and medical innovation. Heroin, of course, started out as a wonder drug, although prohibition dates back to the implementation of the 1914 Harrison Narcotics Act before World War I. In 1947, World Health Organization member countries faced pressure from the United States to ban its medical use entirely. The Canadian Medical Association (CMA) resisted. Dr. A.D. Kelly, the deputy general secretary of CMA, provided a viewpoint supporting heroin on July 23, 1952. "I believe that Canadian doctors feel that diacetylmorphine is a useful drug," he told the House of Commons. ${ }^{3}$ Canada's politicians ignored this advice and chose to restrict heroin for medical purposes in 1955, although this was not a decision taken lightly by Paul Martin Sr., the federal health and welfare minister.

Medical heroin's return in the early 1980 s created a division among experts. One group focused on the viability of the drugs used for pain relief, whereas another group took a broader approach to palliative care. Support for heroin was predicated on its efficacy and use in other jurisdictions, but resistance was based on a philosophy of pain management in palliative care that was about more than just drugs. This was an historical moment, in short, that saw a redefinition of opioids in endof-life care, but also a time at which the prescribing of strong opioids such as oxycodone began to increase dramatically in the US and Canada. ${ }^{4}$

Walker built his argument for medical heroin on evidence of the drug's effectiveness and its ongoing use in the United Kingdom, where the drug was considered "an excellent sedative which is of estimable value in so many conditions." Because it was more soluble, heroin was a faster-acting analgesic than morphine. This was important in treating emaciated patients with little muscle in which to inject a drug, which made receiving a large shot of morphine extremely painful. Walker also argued that heroin was beneficial for those patients troubled by the adverse effects of morphine, including nightmares, nausea, constipation and hallucinations.
By 1982, Walker had collected 30000 signatures on a petition calling for heroin's legalization and an additional 20000 letters supporting his efforts. He had also investigated the use of heroin in the UK. During a fact-finding mission in London, he met with pain specialists, nurses and patients throughout London's hospitals. He visited Scotland Yard, where officials remarked that they had much larger crime concerns than therapeutic heroin. The trip further convinced Walker that heroin was a 
useful tool for physicians and the rules needed to change in Canada. ${ }^{6}$

In the same year, he presented his petition and letters requesting the legalization of heroin to Federal Health and Welfare Minister Monique Bégin in Ottawa. This forced the government into action. She announced the formation of the Expert Advisory Committee on the Management of Severe Pain, populated by physicians and academics from Canada's major research institutions. Dr. Edward Sellers, Professor of Pharmacology and Medicine at the University of Toronto, was Chair, while Dr. Balfour Mount, Professor of Surgery and Director of Palliative Care at McGill University, served as Vice-Chair. ${ }^{7}$

Walker argued that the committee members, including Mount, were opposed to heroin and felt it unlikely that the government would "admit it had been wrong for 29 years." Concerned that the expert committee would stall legalization momentum, he formed the W. Gifford-Jones Foundation in early 1983 to galvanize public sentiment. In May 1983, Minister Bégin declared that the government would initiate extended clinical trials to evaluate the efficacy of heroin relative to morphine and Dilaudid, the other commonly used analgesics for cancer. She stated: "Considering the enormous controversy about heroin, I thought such research was essential." 5

Walker, infuriated by what he perceived to be delaying tactics, believed the available evidence was more than any "other Minister could read in a lifetime." 5 Throughout 19831984, he heightened the rhetoric in his national column, ran full-page advertisements in major newspapers and leaned on his friends in government. He published letters from Canadians whose loved ones had died in excruciating pain, and challenged the Palliative Care Foundation, which opposed his support for new narcotics. Walker also ran a full-page ad in The Globe and Mail criticizing the Canadian Cancer Society's opposition to his agenda. In November 1984, he ran another ad, stating boldly, "This Christmas, will the real hypocrites please stand up."

By this time, allies in the press, medical establishment and government had emerged. In November 1983, an editorial in The Toronto Star announced: "Heroin represents the most effective way some cancer patients can manage the terrible pain that can come with the disease. If these people need it, it should ... be available to them." The Globe and Mail also supported legalization. In June 1984, an editorial attacked the government for "30 years of delay during which cancer patients have faced the ultimate pain without heroin, which is widely used in Britain where there are no political arguments against its medicinal use."

Not only the editorial boards of Canada's major newspapers but also the CMA supported Walker's efforts. Dr. William Ghent proved especially influential. Leading the CMA's Council on Healthcare, he exposed how deception had characterized the original decision to ban heroin. Canada succumbed to US pressures and government ministers, including Paul Martin, who had misled colleagues by suggesting that the CMA supported prohibition. In August 1984, the CMA's general council recommended that physicians be authorized to prescribe heroin, the time being right for Canada to join the 36 other countries using medical heroin. "Heroin was banned," Ghent argued, "on the naive assumption by government and its police forces that if all heroin was illegal, prosecution would be easier and thus illicit use of the drug would be eradicated." He added: "We followed the US like sheep and now, like sheep, we've got their manure to deal with." $3,5,8$

Jake Epp, the new minister of health after the Conservative victory in 1984, was stuck between the CMA's recommendation and that of the Expert Advisory Committee, which had rejected the use of heroin in medical settings. "It is not a technical question which we are addressing," he stated, "but rather the meaning of life and how death with dignity can be enhanced." On Dec. 20, he announced that the government would legalize the use of heroin in cases of severe chronic pain or terminal illness. Epp declared that legal heroin did not pose a threat to the safety of Canadians and that substance abuse would not increase. One pro-heroin supporter in the Ontario government criticized the Expert Advisory Committee as "biased" and "stacked with known opponents of heroin." "It was like Chrysler or Ford looking into Japanese cars." 5
Heroin, however, was more complicated than automobiles. Committee members viewed pain treatment as an interaction of physical, psychological, social and spiritual elements. A single drug, whether heroin or morphine, was not sufficient to address this complicated experience. Mount believed that heroin distracted from crucial issues. ${ }^{5}$ The crisis over its legitimacy meant less attention on anticipating pain and tackling end-of-life care in a holistic manner. Walker, by contrast, viewed access to medical heroin as a way of dealing with cancer in an appropriate and respectful manner. $\mathrm{He}$ insisted that its availability in clinical settings represented a patient-centred approach. Walker also felt the medical community needed to show leadership: "Clinical physicians, not politicians, should make the decision about heroin."

\section{Lucas Richert PhD}

Centre for the Social History of Health and Healthcare, University of Strathclyde, Glasgow, UK

\section{References}

1. Walker K. How a medical journalist helped to legalize heroin in Canada. J Drug Issues 1991;21:143.

2. Walker K. Canadian doctors - lions or lambs? Can Med Assoc J 1982;127:516-7.

3. Da Sylva NP. The CMA's stand on the medical use of heroin: setting the record straight. Can Med Assoc J 1984;130:1515.

4. Leung PT, Macdonald EM, Stanbrook M, et al. A 1980 letter on the risk of opioid addiction. N Engl J Med 2017;376:2194-5

5. Appleby L. The big fix. Saturday Night. 1985:14-5.

6. Gifford-Jones W. You're going to do what?: The memoir of Dr. W. Gifford-Jones. Toronto: ECW Press; 2000:191-3.

7. Scott JF, Sellers EM. Cancer pain, a monograph on the management of cancer pain: a report of the expert advisory committee on the management of severe chronic pain in cancer patients. Ottawa: Health and Welfare Canada; 1984.

8. Kinsella B. Lessons from Canada legalizing heroin for medicine. DPF: Drug Policy Letter, April 22, 1989.

9. Advertisement. The Globe and Mail [Toronto] 1984 Dec. $17 ; 9$.

This article has been peer reviewed.

Lucas Richert is the author of Conservatism, Consumer Choice, and the FDA during the Reagan Era: A Prescription for Scandal (2014), and the recently submitted Strange Medicines: Drugs, Science, and Big Pharma in Culture (2018).

Funded by Wellcome Trust Investigator Award 200394/2/15/2, 2016-2020

This article is part of a series CMAJ is publishing to commemorate the 150th anniversary of the Canadian Medical Association. 